\title{
Judges' Legal Considerations (Ratio Decidendi) and Jurisdical Implications on the Criminal Acts of Continuous Corruption (Study of Supreme Court Decision No. 866 K/Pid. Sus/2016)
}

\author{
Antonius Tigor $\mathrm{W}^{1}$; Rehnalemken Ginting ${ }^{2}$ \\ ${ }^{1}$ Master of Law Student, Faculty of Law, Universitas Sebelas Maret, Surakarta, Indonesia \\ ${ }^{2}$ Lecture in Faculty of Law, Universitas Sebelas Maret, Surakarta, Indonesia \\ http://dx.doi.org/10.18415/ijmmu.v8i12.3186
}

\begin{abstract}
This study intends to examine the legal considerations of the judges of the Supreme Court against the criminal act of corruption continued in the Supreme Court's decision number 866 K/Pid. Sus/2016. The decision stating that the convict is proven to have committed a criminal act of corruption continues, but the continued action is not stated in the consideration of the decision. The Supreme Court's decision number $866 \mathrm{~K} / \mathrm{Pidsus} / 2016$ raises a big question mark regarding the legal basis for criminal prosecution for perpetrators of continuing corruption, this is because the Corruption Crime Law does not specifically regulate acts of continuing corruption. It is said to be a continuous act in a criminal act of corruption because the act is carried out continuously, both with similar crimes in corruption. Continuing action or also called Voorgezette handeling is an act (gebeuren) in which one action with another action is interrelated and becomes a single unit, the linkage must meet at least two conditions, namely the act is the embodiment of a forbidden will decision and an act that is prohibited. happen must be the same. This journal was created with the aim of being able to find out the judge's legal considerations for the criminal act of continuing corruption which was reviewed with the Ratio Decidendi Theory and the academic requirements to obtain a Master of Law degree at the Faculty of Law, Sebelas Maret University, Surakarta. The research method used by the researcher is doctrinal research with a statutory approach and a case approach. The technique of collecting legal materials used is literature study. The legal material analysis technique used is deductive data analysis.
\end{abstract}

Keywords: Ratio Decinendi; Judge's Decision; Corruption Crime

\section{Introduction}

Corruption can cause the Nation and the State to suffer enormous losses. Rustamaji (2019, p. 155) mentions "Corruption as an action taken to pursue profit for them level is actually a matter of social injustice and is a crime against the welfare of the nation and the state", which in Indonesian is defined as corruption is a the act of enriching oneself which is a problem of injustice and crime so that it can harm the nation and state. The term corruption itself comes from one syllable in Latin, namely corruptio or corruptus which is then copied into the language of each country until finally in Dutch it is known as korruptie (Chazawi, 2018). Referring to the Dutch term, the word corruption was born in Indonesian 
(Hamzah, 1991). Corruption in Indonesian can be interpreted as "rotting, destroying, robbing, tarnishing, polluting, confusing, confusing, damaging morals, degrading self-esteem and destroying morals" (Hartiwiningsih, 2020, p. 5).

According to Baharuddin Lopa "corruption is a criminal act related to bribery, manipulation, and other acts as an unlawful act that can harm state finances or the state economy, harm the welfare or interests of the people or the public" (Hartanti, 2007, p. 9). The term corruption in Indonesia provides various understandings of corruption, because they are motivated by their respective perspectives. Since the enactment of Law Number 31 of 1999 concerning the Eradication of Criminal Acts of Corruption, an act of corruption is defined as any person or corporation that unlawfully enriches itself or a corporation that is capable of harming state finances or the state economy.

The entry of gratification as a criminal act of corruption is because gratification is considered a bribe if it is associated with position and has the opposite nature of its obligations or duties as a state civil apparatus or state administrator (Mulyono, 2017). Characteristics of the giver or recipient of gratuities, consisting of:

1. Acceptance of gratuities may bring personal interests accompanied by reciprocal obligations that result in non-independence in the administration of the state;

2. Acceptance of gratuities may affect the objectivity of professional research of state administrators;

3. Acceptance of gratuities can be used in any way to obscure the incidence of criminal acts of corruption. (KPK Pocket Book, 2012)

The arrangement for gratification has similarities with bribery, but the arrangement for gratification is only intended for those who receive only (passive bribes) not those who give (active bribes) (Effendi, 2019). The article is very clear and unequivocal that every bribe received by a state official or civil servant is considered a bribe if the gift is related to his duty or position (Hadifa, 2019). The gratification arrangement in Article 12 B of Law Number 20 of 2001 concerning Amendments to Law Number 31 of 1999 concerning the Eradication of Criminal Acts of Corruption provides a minimum imprisonment of 4 (four) years and a maximum of 20 (twenty) years and a minimum fine of two hundred million and a maximum of one billion rupiah.

According to the Elucidation of Article 12 B of Law Number 20 of 2001, the term gratification is a gift in a broad sense, including the provision of goods, money, rebates, commissions, interest-free loans, travel tickets, lodging facilities, tourist trips, free medical treatment, and other facilities (KPK Pocket Book, 2012). All of these things can be accepted both domestically and abroad by using electronic means or without electronic means (KPK, 2015). Based on the opinion of Soerjono Soekanto which states that good law is law that applies on the basis of three factors, one of which is a sociological factor, namely the law applies if it is forced to apply (accepted or not) and if the law is accepted, recognized, and obeyed by those affected. the law earlier (Ginting, 2018, p. 348). So that law enforcement efforts carried out within the scope of gratification must be based on these legal norms.

One of the law enforcement in the scope of gratification can be found in the Supreme Court Decision Number 866 K/Pidsus/2016. The Supreme Court tried itself and overturned the court's decision at the previous level. The verdict was self-declared and stated that the Processing Director of PT Pertamina (Persero), which was held by Suroso Atmomartoyo, had committed ongoing criminal acts of corruption. Suroso Atmomartoyo is assessed to have received a sum of USD \$ 190,000 (One Hundred Ninety Thousand United States Dollars) and facilities to stay at the Radisson Edwardian May Fair London hotel in the amount of $£ 899.16$ (Eight Hundred and Ninety Nine Pounds Sterling and Sixteen Penny). The amount of USD \$190,000 (One Hundred Ninety Thousand United States Dollars) and accommodation facilities at the Radisson Edwardian May Fair London hotel in the amount of $£ 899.16$ (Eight Hundred Ninety-Nine Pounds Sterling And Sixteen Penny) was a gift from David Peter Turner, 
Paul Jennings, Dennis J Kerisson and Miltos Papachristos through Willy Sebastian Lim and Muhammad Syakir. The prize was given to Suroso Atmomartoyo to continue to purchase TEL (Tetra Ethyl Lead) at the end of 2004 and 2005 through PT Soegih Interjaya. TEL is an additive with a high level of toxicity that is used so that the engine does not sound and increases the octane value of the fuel so that the ability to burn gasoline will be higher as a result of burning TEL, which is a dangerous gas with a level that is very dangerous for health..

The Supreme Court's decision number $866 \mathrm{~K} / \mathrm{Pidsus} / 2016$ raises a big question mark regarding the legal basis for criminal prosecution for perpetrators of continuing corruption, this is because the Corruption Crime Law does not specifically regulate acts of continuing corruption. Not yet specifically regulated acts of corruption continue in the Law on the Eradication of Criminal Acts of Corruption, providing in-depth questions regarding the juridical implications of punishment for perpetrators of criminal acts of corruption continues in the Supreme Court Decision Number $866 \mathrm{~K} / \mathrm{Pid} . \mathrm{Sus} / 2016$. It is said to be a continuous act in a criminal act of corruption because the act is carried out continuously, both with similar crimes in corruption. (Rijal, 2020). Continuing action or also called Voorgezette handeling is an act (gebeuren) in which one action with another action is interrelated and becomes a single unit, the linkage must meet at least two conditions, namely the act is the embodiment of a forbidden will decision and an act that is prohibited. occurs must be of the same type (Hiariej, 2014).

Based on the arguments described above, the researcher is interested in examining the judge's legal considerations for the criminal act of corruption, continuing with the Supreme Court's decision Number $866 \mathrm{~K} / \mathrm{Pid}$.Sus/2016. The issues that will be raised are related to how the judge's legal considerations ( Ratio Decidendi) to the criminal act of corruption continues in the Supreme Court's decision number $866 \mathrm{~K} / \mathrm{Pid}$. Sus/2016.

\section{Methods}

This research is a normative legal research. This study confirmed that "the appropriate approach used in this legal research is the statute approach, the case approach, and the conceptual approach". In this study, researchers used techniques. The data collection technique used in this study was a document study. This study uses the technique of analyzing legal materials with deductive logic, according to Peter Mahmud Marzuki who quoted Philipus M. Hadjon's opinion explaining the deduction method as the syllogism taught by Aristotle, the use of the deduction method stems from the submission of the major premise (general statement) then put forward the premise minor (special nature) of the two premises and then draw a conclusion or conclusion.

\section{Results and Discussion}

Supreme Court Decision Number 866 K/Pid. Sus/2016 is a decision of cassation against the corruption case of continuous gratification carried out by the convict Suroso Atmomartoyo while serving as the Processing Director of PT. PERTAMINA (Persero). The Supreme Court's decision was born because of a cassation request submitted by both the Public Prosecutor and the Defendant, so according to the researcher to be able to answer the formulation of the problem, Judex Facti decisions at the previous level are needed. According to Peter Mahmud Marzuki (2009) to find the ratio decidendi in a decision generally can be found in certain parts. To be able to reach a decision, a judge must write down the reasons called the ratio decidendi. The ratio decidendi in Indonesian law, which adheres to the civil law legal system, can be found in the "Considering" the "Main Case".

Based on the Ratio Decidendi Theory presented by MacKenzie, the judge when going to make a decision, the judge must have a basic philosophical foundation and relate to the basis of applicable laws and regulations and in accordance with the subject matter and motivation of the judge who is clear as an effort law enforcement and provide justice for the parties (Rifai, 2010). In addition, judges are also 
required to pay attention to educational (education) factors, humanity, benefits, law enforcement and legal certainty in giving a decision (Rustamaji, 2020).

\section{Philosophical Foundations Related to the Basis of Applicable Laws and Regulations}

The philosophical foundation is the foundation on how to think far and wide and in depth to be able to find the truth regarding forms, sources of knowledge, ethics and aesthetics (Gunawan, Without Years), therefore when it is associated with the Supreme Court Decision Number 866 K/Pid. Sus/2016, the Supreme Court Judge in his decision must have these things as the basis and be linked to the applicable laws and regulations. Based on the description of the results of the research on the Supreme Court Decision Number $866 \mathrm{~K} / \mathrm{Pid}$. Sus/2016, Supreme Court Judges no longer examine legal events/facts and prove Judex Factie's decisions. Judges of the Supreme Court use their authority to adjudicate the Continuing Corruption Crimes committed by the convicts themselves. This resulted in the Supreme Court Judge canceling the Corruption Court Decision at the Jakarta High Court Number 46/PID/TPK/2015/PT.DKI dated January 19, 2016 which amended the Corruption Court Decision at the Central Jakarta District Court Number 46/Pid.Sus /TPK/2015/PN.JKT.PST dated October 19, 2015. The judge of the Supreme Court was of the opinion that the Judex Facti decision had incorrectly applied the law as it should have been because it released the convict from Article 18 paragraph (1) letter b of the Law of the Republic of Indonesia Number 31 Year 1999 as amended by the Law of the Republic of Indonesia Number 20 of 2001. The judges of the Supreme Court also disagreed with Judex Factie's consideration that the value of money was USD 190,000 (one hundred and ninety thousand United States Dollars) in Account Number 380-009-405 -2 at Bank UOB Singapore has not been enjoyed by the Defendant and its control has not been transferred to another party.

The researcher found the motivation for law enforcement against the convicts in the Supreme Court Judges with the annulment of the Corruption Court Decision at the Jakarta High Court Number 46/PID/TPK/2015/PT.DKI dated January 19, 2016. This can be found in the considerations of the Supreme Court Decision Number 866 K/Pid. Sus/2016:

Whereas even though the Indictment of the Public Prosecutor at the Corruption Eradication Commission does not include Article 18 paragraph (1) letter b of the Law of the Republic of Indonesia Number 31 of 1999 jo. Law of the Republic of Indonesia Number 20 of 2001 concerning Eradication of Criminal Acts of Corruption, but in accordance with the provisions of Article 17 of the Law on the Eradication of Criminal Acts of Corruption which states that in addition to being subject to criminal penalties as referred to in Article 2, Article 3, Article 5, to Article 14 The Law on the Eradication of Criminal Acts of Corruption, to the Defendant who has been sentenced to imprisonment as regulated and determined in Article 12 letter b, the second alternative charge based on the Judex Facti a quo decision, may be subject to additional punishment in the form of payment of replacement money as referred to in Article 18 of the Law. -Law on the Eradication of Corruption Crimes;

The motivation for law enforcement in question is an effort to complete the Judex Factie decision, because the Supreme Court Judge believes that the convict can be sentenced to additional punishment in the form of payment of compensation. According to the researcher, completing the Judex Factie Decision is part of law enforcement efforts carried out by Supreme Court Judges at the Cassation level so that in the end positive law can be enforced and corruption can be eradicated. According to the researcher, the judges of the Supreme Court have the authority to adjudicate themselves in the Supreme Court's Decision Number $866 \mathrm{~K} / \mathrm{Pid}$. Sus/2016 shows a source of knowledge related to the main tasks of the Supreme Court Judge, which is in accordance with Article 30 paragraph (1) of Law Number 5 of 2004 concerning Amendments to Law Number 14 of 1985 concerning the Supreme Court. The article gives the Supreme Court authority at the cassation level court because of three things, namely not having the authority or exceeding the limits of authority, incorrectly applying or violating the applicable law, and failing to fulfill 
the conditions required by the laws and regulations that threaten the negligence with the cancellation of the decision made. concerned.

Supreme Court Decision Number $866 \mathrm{~K} / \mathrm{Pid}$. Sus/2016 which annulled the Corruption Court Decision at the Jakarta High Court Number 46/PID/TPK/2015/PT.DKI, has a difference from other Court Decisions at the previous level or what is called Judex Factie. The difference consists of 3 important points, namely the imposition of the main crime, the imposition of additional penalties and the judge's considerations regarding the Continuing Corruption Crime. These three differences as a result of the cancellation of the Jakarta High Court Number 46/PID/TPK/2015/PT.DKI can show aspects of education, humanitarian aspects, aspects of legal certainty and law enforcement that are considered by Supreme Court judges.

The difference to the main crime in the Supreme Court Decision Number 866 K/Pid. Sus/2016 is not too much, because the main punishment in the form of imprisonment is 7 (seven) years which was originally by the Jakata High Court sentenced to 6 (six) years in prison and the Central Jakarta District Court 5 (five) years. Meanwhile, for the main punishment in the form of a fine, the Judge of the Supreme Court still imposes a fine of Rp. 200,000,000 (two hundred million rupiah) with the stipulation that if the fine is not paid, it will be replaced with imprisonment for 6 (six) months. The imposition of the principal criminal in the form of a fine made by the Judge of the Supreme Court is still the same as the decisions of the Court of the previous level. Imprisonment is a criminal form of deprivation of liberty that can only be granted through a court decision (Hiariej, 2014). Hiariej also mentions (Hiariej, 2014) that a fine or what is called a fine is imposed as a form of rejection of the implementation of a corporal punishment in a short time, so that when it is associated with the Supreme Court Decision Number $866 \mathrm{~K} / \mathrm{Pid}$. Sus/2016, the convict has the opportunity to be able to pay the fine if he wants to be released from imprisonment for 6 (six) months.

The next difference is Supreme Court Decision Number 866 K/Pid. Sus/2016 from the Court's Decision at the previous level was regarding the imposition of additional penalties. Judges of the Supreme Court have a different view from the Court's Decision at the previous level which did not impose additional penalties on the convict. The judge of the Supreme Court is of the opinion that the convict deserves to be imposed Article 18 paragraph (1) letter b of the Law of the Republic of Indonesia Number 31 of 1999 as amended by the Law of the Republic of Indonesia Number 20 of 2001 even though the Public Prosecutor's indictment does not include that article. Additional punishment is in the form of an order to pay a replacement money of USD 190,000 (one hundred and ninety thousand United States dollars) and if the Defendant does not pay the replacement money no later than 1 (one) month after the court's decision has permanent legal force, the convict's assets can be confiscated. and auctioned to cover the replacement money, and in the event that the convict does not have sufficient assets to pay the replacement money, then it is replaced with imprisonment for 2 (two) years. According to the researcher, the additional punishment imposed on the convict is a form of confiscation of certain assets, even though the Supreme Court Judge still gives the convict an opportunity to make a replacement payment of USD 190,000 (one hundred and ninety thousand United States dollars). The opportunity to pay first before the confiscation is carried out is a form of humanity from the Supreme Court Judge to the convict in terms of possession of certain goods.

The fundamental difference from the Supreme Court Decision Number 866 K/Pid. Sus/2016 from the Court's Decision at the previous level was regarding the consideration of the Supreme Court Judge regarding continued corruption. In the decision, the Court Judge did not describe the criminal acts committed by the convict in detail as in the Central Jakarta District Court Decision. This can be found in: The defendant received a gift from the Director of PT. Soegih Interjaya (SI) / Muhammad Syahir in the amount of USD 190,000 (one hundred and ninety thousand United States dollars) related to the approval of PT. Soegih Interjaya (SI) as a supplier of Tetra Ethyl Lead (TEL) for Pertamina. 
According to the researcher, this has resulted in the continued absence of the criminal acts of corruption committed by the convict while serving as the processing director of PT Pertamina (Persero) and making the convict's actions appear as if it were a criminal act of corruption in general. This is in contrast to the Panel of Judges examining the case at the Central Jakarta District Court which has clearly stated in its considerations the fulfillment of the element of continuing action as regulated in Article 64 paragraph (1) of the Criminal Code. According to the Panel of Judges of the Central Jakarta District Court:

Considering, that based on the legal facts as described in the element of "giving gifts" above, it can be concluded that the Defendant in receiving a gift in the form of money from WILLY SEBASTIAN LIM as a result of having purchased TEL which was carried out contrary to his obligations in his position as Director of Processing of PT Pertamina was received several times in a row, namely: a. On January 18, 2005, amounting to USD 120,000 (one hundred and twenty thousand United States dollars). b. On July 13, 2005, amounting to USD 40,000 (forty thousand United States dollars). c. On September 26, 2005, amounting to USD 30,000 (thirty thousand United States dollars).

Considering, whereas the Defendant committed the act of accepting a gift in the form of money in stages and the facilities for staying at the Hotel in the interval between the first and the following were not too long, namely between January 17, 2005 to September 2005.

Thus, the actions of the Defendant Suroso Atmomartoyo must be seen as a continuing act (voorgezette handling) so that the elements of Article 64 Paragraph (1) of the Criminal Code have been fulfilled according to law.

Court decisions that adjudicate criminal acts of corruption continue to be something that the convict or parties involved in it look forward to, because these parties expect legal certainty and justice (Makarao, 2004). The unwritten act of corruption continues in the consideration of the Supreme Court Judge, making the decision a decision that only implies that the criminal act of corruption continues. This fundamental difference is related to Article 25 paragraph (1) of Law No. 4 of 2004 concerning Judicial Power, especially regarding the necessity to contain the reasons and basis for the decision, as well as to include articles of statutory regulations, the description of the judge's considerations and the articles of legislation that apply have no correlation. The absence of the main relevance of the case (the criminal act of corruption continues) with the applicable laws and regulations, undermines the motivation of Supreme Court Judges in carrying out law enforcement and providing justice.

Researchers do not agree with the Supreme Court Decision Number 866 K/Pid. Sus/2016 regarding the stipulation of convicts committing criminal acts of corruption on an ongoing basis. The researcher disagrees because it is motivated by the application of the Criminal Legality Principle. The principle of legality derived from the adagium nullum delictum, nulla poena sine praevia legi poenali (Hiariej, 2014) means that an event cannot be punished, other than the strength of the criminal regulations that preceded it (Pramono, 2020). The principle of legality in criminal law can be found in Article 1 paragraph (1) of the Criminal Code. The article provides protection to the people from the exercise of unlimited power, especially the function of the criminal law (Pramono, 2020). According to the researcher, the decision must be handed down in accordance with the actions that have been carried out and the actions have been previously regulated in a regulation. Against criminal acts of corruption, especially gratification which is carried out many times and continues, it has not been found or has not been regulated in the Law on eradicating corruption. According to the researcher, the verdict should only mention the actions of the Defendant as a "Corruption Crime" without having to mention "continuously". For acts of gratification carried out by the defendant on an ongoing basis, according to the researcher, it should be part of the judge's consideration to burden the sentence imposed on the defendant. 


\section{Factors of Education (education), Humanity, Benefit, Law Enforcement and Legal Certainty;}

MacKenzie in the Ratio Decidendi Theory reminds that judges must pay attention to educational (education) factors, humanity, expediency, law enforcement and legal certainty in giving a decision (Rustamaji, 2020). Thus, it is hoped that in a judge's decision, these four factors can be found so that it can be said to be a good decision. When associated with decision number $866 \mathrm{~K} / \mathrm{Pid}$. Sus/2016 which is the result of the authority to try judges of the Supreme Court themselves, the four factors can be reviewed as follows:

a. Legal Certainty Factors.

The factor of legal certainty related to criminal acts of corruption continues in the decision Number $866 \mathrm{~K} / \mathrm{Pid}$. Sus/2016 did not pay close attention to the judges of the Supreme Court. The Judge of the Court is of the opinion that the Corruption Court's Decision at the Jakarta High Court Number 46/PID/TPK/2015/PT.DKI dated January 19, 2016 which amended the Corruption Court's Decision at the Central Jakarta District Court Number 46/PID/TPK/2015/ PT.DKI dated October 19, 2015 could no longer be maintained because Judex Facti's legal considerations were deemed inappropriate and inappropriate. The consequence of the annulment of the decision is that the entire content which includes the considerations and orders of the Judex Facti Panel of Judges is canceled, so that the Jakarta High Court's legal considerations that have agreed with the considerations of the Central Jakarta District Court judges on the evidence of continued corruption committed by the convict are also null and void. .

The judges of the Central Jakarta District Court did not rewrite the judgments of the judges at the Central Jakarta District Court regarding the criminal act of continuing corruption by the Supreme Court judges and based on the combined theory of punishment, especially related to continuing acts, Rustamaji explained that continuing acts can occur when a person commits several criminal acts, each of which is an individual act. itself, but every act is related to each other and must be considered as a continuing act (Rustamaji, 2020), making the decision on cassation Number $866 \mathrm{~K} / \mathrm{Pid}$. Sus/2016 as a cassation decision that forced an act of corruption to continue to the convict. This is because, there is no element of continuing action and the relevance between the judge's considerations and the applicable laws and regulations as well as the decision handed down to the convict.

b. Benefit Factor

The judge of the Supreme Court pays attention to the benefit factor to the convict. Convicted through Decision Number $866 \mathrm{~K} / \mathrm{Pid}$. Sus/2016 has been given the opportunity to improve himself so that he does not repeat the criminal act of corruption continues. The judge of the Supreme Court with his decision seemed to be trying to provide benefits to the State in the form of setting a replacement money of USD 190,000 (one hundred and ninety thousand United States dollars) if he did not pay the replacement money no later than 1 (one) month after the court's decision has permanent legal force. All assets belonging to the convict can be confiscated and auctioned and if the convict's assets are not sufficient then it is replaced with imprisonment for 2 (two) years. Judges of the Supreme Court are more considerate of imposing criminal sanctions that are beneficial to the convict for the crime he has committed, thus it is hoped that a sense of deterrence will be created from the convict.

c. Human Factor

Human factors in the decision of $866 \mathrm{~K} / \mathrm{Pid}$. Sus/2016 has been considered by the Judges of the Supreme Court, namely by considering the productive age side of the convicts so that they are expected to improve themselves in the future. In addition, the Supreme Court Judge also pays attention to the history of the convict who has never committed a crime. The humanitarian factor 
inherent in the convict is also considered by the Supreme Court Judge with the aim of being able to provide an integrative punishment to the convict, meaning that the sentencing decision is made by the Supreme Court Judge in order to fulfill the dimensions of justice for the convict, the community, and even the interests of the State (Pramono, 2020).

Another humanitarian factor that is considered by the Supreme Court Judge is related to the weight of the imprisonment for 7 (seven) years for the convict which pays attention to the type of crime that has been committed by the convict is a criminal act of continued corruption in the form of accepting a bribe of USD 190,000 (one hundred and ninety thousand dollars). United States), then the prison sentence imposed by the Supreme Court Judge is quite light. According to the researcher, the light imprisonment imposed on the convict is only for preventive purposes, so that the behavior of criminal acts of corruption continues not to be imitated by other people so that in the end the eradication of corruption in Indonesia can be successful.

The lack of attention to the legal certainty factor in the ratio decidendi due to the inaccuracy of the Supreme Court Judge in rewriting the criminal act of corruption continued to the cassation decision which canceled the court's decision at the previous level which resulted in the unspoken act of corruption continuing, so that the application of the law in sentencing the convicts was not done. fulfill human values. According to the researcher, the legal consequences that must be borne by the Supreme Court Judge by canceling the previous court decision are that everything contained in the judge's legal considerations comes from legal facts in the trial and applies to replace the facts in the previous court decision. If the criminal act of corruption continues, the convict cannot be subject to Article 64 paragraph (1) of the Criminal Code as well as Article 12 letter (b) of Law Number 20 of 2001 in conjunction with Law Number 31 of 1999. Judges of the Supreme Court do not pay attention to the humanitarian factor for the convict.

\section{d. Educational Factor}

The educational factor that is considered by the judge through consideration is that every Indonesian citizen should be able to participate with the Government in efforts to eradicate corruption, there should be self-awareness not to commit corruption. Another message is that every Indonesian citizen who occupies a vital position in the State should be able to maintain the good name of the Indonesian Nation and State with one of his efforts, namely not committing a criminal act of corruption. Decision number $866 \mathrm{~K} / \mathrm{Pid}$. Sus/2016 is expected to be able to improve itself and become an example for the general public so that they are more afraid to commit criminal acts of corruption in general and criminal acts of corruption continue in particular.

The Decidendi Ratio of the cassation decision shows that the philosophical foundation has not been achieved in relation to the applicable laws and regulations, especially those related to continuing acts of corruption. It is not stated that the criminal act of corruption continues, the convict should not be subject to Article 64 paragraph (1) of the Criminal Code as well as Article 12 letter (b) of Law Number 20 of 2001 in conjunction with Law Number 31 of 1999, therefore the punishment of criminal acts corruption continues to contain a combined theory of punishment, namely between absolute and relative punishment. The adoption of absolute punishment cannot be separated from the efforts of the Supreme Court Judges who continue to impose the main criminal sentence and it seems that the cassation decision is only an effort to find the party who must be responsible. Meanwhile, punishment is relatively motivated by the efforts of Supreme Court Judges to create preventive measures with the aim that continuing corruption crimes can be prevented.

The juridical implications of being convicted of criminal acts of corruption continue to affect the achievement of legal objectives which consist of three basic legal values. The ratio decidendi of judges of the Supreme Court in convicting criminal acts of corruption has shown that the factor of legal certainty, 
especially due to the inaccuracy of Judges of the Supreme Court in pouring out continuing actions in criminal acts of corruption committed by the convict. The three basic legal values consist of the value of justice, benefit and value of legal certainty. The lack of attention to the legal certainty factor in the ratio decidendi of the criminal act of corruption continues to affect the creation of the value of justice, this is because the law should be able to bring human values in order to create justice in society.

Ignoring the legal certainty factor related to continuing actions and having affected human values, will automatically affect the legal basis for the benefits or finality of the sentencing that has been committed. This means that the punishment carried out by the Supreme Court Judge by leaving the legal certainty factor as well as human values and justice makes the punishment carried out by the Supreme Court Judge not useful. It is not stated that the criminal act of corruption continues, the convict should not be subject to Article 64 paragraph (1) of the Criminal Code as well as Article 12 letter (b) of Law Number 20 of 2001 in conjunction with Law Number 31 of 1999, Judges of the Supreme Court try to maintain the value of evidence that has been obtained at the trial at the Central Jakarta District Court, but this effort has actually forced the creation of legal certainty in the Supreme Court Decision Number 866 K/Pid. Sus/2016. According to the researcher, the value of legal certainty is forced to be created as an effort to impose criminal penalties that can harm the fate of the convict's life.

\section{Conclusion}

The absence of a continued corruption crime in the consideration of the judges of the Supreme Court, makes the judge's decision only implying that the criminal act of corruption continues by the convict mentioned in the verdict. Supreme Court Decision Number 866 K/Pid. Sus/2016 which has been based on a philosophical foundation related to the applicable laws and regulations can be one of the decisions that provide education and benefits for the community and especially in law enforcement in Indonesia. On the other hand, the absence of an explicit corruption case continues in the consideration of the Supreme Court Judges who have overturned the court's decision at the previous level, creating the judge's negligence on the factor of legal certainty. The absence of a continuing act of corruption in the consideration of the judges of the Supreme Court causes the application of Article 64 paragraph (1) of the Criminal Code related to continuing acts to be irrelevant to the judge's consideration as a legal fact that occurred.

\section{References}

Buku Saku KPK. (2012). Memahami Gratifikasi. Jakarta: KPK.

Chazawi, A. (2018). Hukum Pidana Korupsi Di Indonesia (Edisi Revisi). Depok: Rajawali Pers.

Effendi, T. (2019). Buku Ajar Pemberantasan Tindak Pidana Korupsi. Surabaya: Scopindo Media Pustaka.

Ginting, R. (2018). Fungsionalisasi Hukum Pidana Dalam Menangani Kekerasan Massa Mei 1998. Surakarta: Disertasi Program Doktor Ilmu Hukum Pascasarjana Fakultas Hukum Universitas Sebelas Maret.

Gunawan, I. (Tanpa Tahun, Tanpa Bulan Tanpa Tanggal). Landasan Filsafat. Retrieved Oktober 19, 2021, from http://fip.um.ac.id/wp-content/uploads/2015/12/3.3_Landasan-Filsafat.pdf,

Hadifa, L. (2019). Membangun Budaya Anti Korupsi Di Lingkungan Organisasi Pemerintah Daerah. Kendari: Adiprima Pustaka.

Hamzah, A. (1991). Korupsi Di Indonesia. Jakarta: Sinar Grafika. 
Hartanti, E. (2007). Tindak Pidana Korupsi. Jakarta: Sinar Grafika.

Hartiwiningsih. (2020). Probelamtika Dan Strategi Pemberantasan Korupsi, Kolusi, Dan Nepotisme Di Indonesia. Surakarta: UNS Press.

Hiariej, E. O. (2014). Prinsip-Prinsip Hukum Pidana . Yogyakarta: Cahaya Atma Pustaka.

KPK. (2015). Pedoman Pengendalian Gratifikasi. Jakarta: KPK.

Makarao, M. T. (2004). Pokok-Pokok Hukum Acara Perdata (1 ed.). Jakarta: PT. Rineka Cipta.

Marzuki, P. M. (2009). Pengantar Ilmu Hukum. Jakarta: Kencana.

Mulyono, A. (2017). Tindak Pidana Gratifikasi. Yogyakarta: Genta Publishing.

Pramono, B. (2020). Peradilan Militer Indonesia. Surabaya: Scopindo.

Rian Saputra, Development of Creative Industries as Regional Leaders in National Tourism Efforts Based on Geographical Indications. Jurnal Bestuur Vol. 8, Issue 2, December, 2020.

Rian Saputra, Pergeseran Prinsip Hakim Pasif Ke Aktif Pada Praktek Peradilan Perdata Perspektif Hukum Progresif. Wacana Hukum . Vol 2 No 1, Juni 2019

Rifai, A. (2010). Penemuan Hukum oleh Hakim: Perspektif Hukum Progresif. Jakarta: Sinar Grafika.

Rijal, H. (2020). Tindak Pidana Korupsi Yang Dilakukan Secara Berlanjut Oleh Tim Pengelola Jaminan Persalinan Dinas Kesehatan Kabupaten Langkat (Putusan Mahkamah Agung Nomor: 2301K/Pid. Sus/2015). Medan: Skripsi Universitas Pembangunan Panca Budi Medan.

Rustamaji, M. (2020). Hukum Pidana Umum. Yogyakarta: Thafa Media.

Rustamaji, M. (2019). The Study Of Mutual Legal Assistance Model And Asset Recovey In Corruption Affair. Indonesia Journal Of Criminal Law Studies , 2, 155.

\section{Copyrights}

Copyright for this article is retained by the author(s), with first publication rights granted to the journal.

This is an open-access article distributed under the terms and conditions of the Creative Commons Attribution license (http://creativecommons.org/licenses/by/4.0/). 